Tropical Journal of Pharmaceutical Research May 2016; 15 (5): 1089-1098

ISSN: $1596-5996$ (print); 1596-9827 (electronic)

(C) Pharmacotherapy Group, Faculty of Pharmacy, University of Benin, Benin City, 300001 Nigeria.

All rights reserved.

Available online at http://www.tjpr.org

Review Article

http://dx.doi.org/10.4314/tjpr.v15i5.27

\title{
Natural plant polyphenols for alleviating oxidative damage in man: Current status and future perspectives
}

\author{
Jiao-Kun Li ${ }^{1,2}$, Xue-Duan Liu ${ }^{2}$, Li Shen ${ }^{2}$, Wei-Min Zeng ${ }^{2 \star}$ and Guan-Zhou Qiu ${ }^{2}$ \\ ${ }^{1}$ School of Metallurgy and Environment, ${ }^{2}$ School of Minerals Processing and Bioengineering, Central South University, \\ Changsha 410083, China
}

*For correspondence: Email: zengweimin1024@sina.com; qgzhoucsu@163.com; Tel: +86-731-8887-7472

\begin{abstract}
The balance between oxidation and reduction is important for maintaining a healthy biological system. Oxidative stress results from an imbalance between excessive formation of reactive oxygen species (ROS) and/or reactive nitrogen species (RNS) and limited endogenous defense systems, and this imbalance can adversely alter lipids, proteins and DNA, causing a number of human diseases. Thus, exogenous antioxidants that can neutralize the effect of free radicals are needed to diminish the cumulative effects of oxidative damage over human life span. Current research reveals that phenolic compounds in plants possess high antioxidant activity and free radical scavenging capacity and can prevent the body from oxidative damage over human life span. This review focuses on the present understanding of free radicals and antioxidants and their importance in human health and disease. Information about the chemical features of free radicals as well as their deleterious effects on cell structures is reviewed. The chemical structure and anti-oxidative mechanisms of essential polyphenols and their potential health benefits are presented. In addition, the limitation of natural antioxidants and a perspective on likely future trends in this field are also discussed.
\end{abstract}

Keywords: Free radicals, Oxidative stress, Natural antioxidants, Polyphenols, Health benefits, Reactive oxygen species, Reactive nitrogen species

Tropical Journal of Pharmaceutical Research is indexed by Science Citation Index (SciSearch), Scopus, International Pharmaceutical Abstract, Chemical Abstracts, Embase, Index Copernicus, EBSCO, African Index Medicus, JournalSeek, Journal Citation Reports/Science Edition, Directory of Open Access Journals (DOAJ), African Journal Online, Bioline International, Open-J-Gate and Pharmacy Abstracts

\section{INTRODUCTION}

Oxidation is a chemical reaction involving transfer of an electron from electron - rich to electron - deficient entity. In human body, the oxygen molecule $\left(\mathrm{O}_{2}\right)$ is an element indispensable for life and used biologically to oxidize (burn) carbon-and hydrogen-rich molecules to obtain chemical energy and heat [1]. However, oxygen is a dangerous friend. The by-products of its metabolism called free radicals, usually including reactive oxygen species (ROS) and reactive nitrogen species (RNS) are unstable, violently reactive and potentially destructive [2]. Although ROS and
RNS exert beneficial effects on cellular responses and immune function at low/moderate levels, they also can damage all cell structures at high concentrations (termed as oxidative stress), leading to a number of diseases such as cancer, aging, cardiovascular and neurodegenerative diseases $[3,4]$.

Antioxidants are substances capable of preventing or slowing the oxidation of other molecules. They exert their protective action either by suppressing the formation of free radicals or by scavenging free radicals [5]. However, oxidative stress occurs in the body when there is a serious imbalance between the 
generation of free radicals and the antioxidant defence systems [6]. Despite the fact that humans naturally produce antioxidants, the process is not effective under some physiopathological situations (cigarette smoke, air pollutants, UV radiation, inflammation) $[7,8]$. Thus, increasing the antioxidant intake can prevent diseases and lower the health problems caused by free radicals. Plants, especially the medicinal plants are important sources of antioxidant substances, which can inhibit free radical formation and/or interrupt propagation of autoxidation. In recent years, plant polyphenols have gained a lot of importance because of their potential use as prophylactic and therapeutic agents in many diseases related to oxidative stress and free radical-induced damage.

\section{BASICS OF FREE RADICAL RESEARCH}

\section{Free radicals}

The term 'free radicals' is defined as the reactive molecular species that contain unpaired electrons in their outermost orbital [2,3]. Free radicals can be formed from molecules by the homolytic fission of a chemical bond and via redox reactions, which is a far more common process in biological systems [2]. In popular scientific/biomedical literature, 'free radical' is used in a broad sense and also includes related reactive species such as 'excited states' that lead to free radical generation or those species that result from free radical reactions. Usually, free radicals are very short - lived and derived from two elements: oxygen and nitrogen, thus creating highly reactive molecules like reactive oxygen species (ROS) and reactive nitrogen species (RNS). ROS include superoxide anion radicals $\left(\mathrm{O}_{2}^{-*}\right)$, reactive hydroxyl radicals $\left(\mathrm{OH}^{*}\right)$, hydroperoxyl radical $\left(\mathrm{HO}_{2}{ }^{\circ}\right)$ and other species like hydrogen peroxide $\left(\mathrm{H}_{2} \mathrm{O}_{2}\right)$, hypochlorous acid $(\mathrm{HOCl})$ and singlet oxygen $\left({ }^{1} \mathrm{O}_{2}\right)$ [9]. The nitrogen-derived free radicals are nitric oxide $(\mathrm{NO})^{\circ}$, nitrogen dioxide $\left(\mathrm{NO}_{2}\right)$, peroxy-nitrite anion $\left(\mathrm{ONOO}^{-}\right)$[10].

\section{Oxidative damages induced by free radicals}

Although structurally different, the presence of unpaired electron results in free radicals sharing common properties, oxidizing other molecules to gain electrons and stabilizing themselves. Free radicals can attack important macromolecules in the human body, including lipids, proteins and DNA [11], and have been implicated as the cause of cancer, aging and neurodegenerative diseases such as Alzheimer's disease, Parkinson disease and cardiovascular diseases such as arteriosclerosis. They are also the primary cause of cell death and tissue damage resulting from heart attack and stroke [12]. Lipids are more susceptible to free radical damage among all the major classes of biomolecules. When they react with membrane lipids, free radicals cause lipid peroxidation (LP). The consequences of lipid peroxidation are cross linking of membrane proteins, change in membrane fluidity and formation of adducts with protein and DNA which may be detrimental to the functioning of the cell [13]. In addition, a large number of toxic products are also formed due to lipid peroxidation, such as malondialdehyde (MDA), 4-hydroxynonenal (4$\mathrm{HNE}$ ) and various 2-alkenals.

Proteins can be oxidatively modified in three distinct ways: oxidative modification of a specific amino acid, free radical-mediated peptide cleavage, and formation of protein cross-linkage due to reaction with lipid peroxidation products [14]. The side chains of all amino acid residues of proteins, in particular tryptophan, cysteine and methionine residues are susceptible to oxidation [15]. Free radical mediated protein modification increases susceptibility to enzyme proteolysis. In addition, oxidative damage to cellular proteins can affect the signal transduction pathways, enzyme activity and heat stability which leads to aging [16].

Although DNA is a stable, well-protected molecule, ROS/RNS still can interact with it and cause several types of damage such as production of base-free sites, deletions, modification of all bases, frame shifts, double strand DNA breaks, DNA-protein cross-links and chromosomal arrangements [17]. Because oxidative damage to DNA can affect the cell cycle and lead to mutations, DNA alteration has been suggested to be responsible in part in carcinogenesis $[18,19]$.

\section{Source of free radicals in human body}

Free radicals and other ROS are derived either from endogenous metabolic process in the human body or from external sources, such as exposure to X-rays, ozone, cigarette smoking, air pollutants, and industrial chemicals. In the cells, formation of ROS and RNS can occur continuously as a consequence of both enzymatic and non-enzymatic reactions. Enzymatic reactions generating free radicals include those involved in the respiratory chain, in phagocytosis, in the prostaglandin synthesis, and in the cytochrome P450 system [20]. Mitochondria have long been recognized as the major site for ROS production and both complexes I and III have been established to be the specific sites for mitochondrial ROS 
generation [21,22]. Besides mitochondria, many enzymes are also capable of producing ROS, such as, NADPH oxidase, xanthine oxidase, Damino acid oxidase and dihydrolipoamide dehydrogenase [23]. For example, the superoxide anion radicals $\left(\mathrm{O}_{2}^{-{ }^{-}}\right)$is generated via cellular oxidase systems, such as $\mathrm{NADPH}$ oxidase, xanthine oxidase, peroxidases. Hydrogen peroxide $\left(\mathrm{H}_{2} \mathrm{O}_{2}\right)$ is produced by the action of several oxidase enzymes, including amino acid oxidase and xanthine oxidase. In particular, xanthine oxidase catalyzes the reaction of hypoxanthine to xanthine and xanthine to uric acid. In both steps, molecular oxygen is reduced, forming the superoxide anion in the first step and hydrogen peroxide in the second [20-22]. Hydroxyl radical $\left(\mathrm{OH}^{\circ}\right)$, the most reactive free radical is formed by the reaction of $\mathrm{O}_{2}^{-}$with $\mathrm{H}_{2} \mathrm{O}_{2}$ in the presence of $\mathrm{Fe}^{2+}$ or $\mathrm{Cu}^{+}$(the Fenton reaction) [24]. The various pathways involved in the generation of some of the reactive oxygen species are given in Figure 1. In addition, free radicals can also be formed in nonenzymatic reactions of oxygen with organic compounds as well as those initiated by ionizing radiations.

\section{Oxidative stress and antioxidant protection mechanisms}

In general, free radicals as necessary intermediates are produced in a variety of normal biochemical reactions and a homeostatic balance exists between free radical generation and quenching under normal physiological conditions $[25,26]$. Oxidative stress occurs when this balance is disrupted by excessive production of reactive oxygen species. Antioxidants are central to the redox balance in the human body. The term 'antioxidant' refers to any molecule stable enough to donate an electron to a rampaging free radical and neutralize it, thus reducing its capacity to damage a target molecule $[2,3]$. Antioxidants may exert their effects by different mechanisms, such as suppressing the production of active species by reducing hydroperoxides and $\mathrm{H}_{2} \mathrm{O}_{2}$ and also by sequestering metal ions, termination of chain reaction by scavenging active free radicals, repairing and/or clearing damage of cell. Similarly, some antioxidants also induce the biosynthesis of other antioxidants or defence enzymes [27].

Humans have several mechanisms to counteract oxidative stress, either by producing antioxidants from endogenous antioxidant systems or externally supplied through exogenous antioxidants (Figure 2). The endogenous antioxidant systems, including enzymatic and non-enzymatic antioxidants, play a crucial role in maintaining optimal cellular functions. The major antioxidant enzymes directly involved in the neutralization of ROS and RNS are superoxide dismutase (SOD), catalase (CAT), glutathione peroxidase (GPx), glutathione reductase (GRx) $[3,28]$. SOD, the first line of defense against free radicals, catalyzes the dismutation of $\mathrm{O}_{2}^{-\cdot}$ to $\mathrm{O}_{2}$ and to the less-reactive species $\mathrm{H}_{2} \mathrm{O}_{2}$ by reduction. In humans there are three forms of SOD: cytosolic $\mathrm{Cu}, \mathrm{Zn}-\mathrm{SOD}$, mitochondrial $\mathrm{Mn}$ SOD, and extracellular SOD (EC-SOD) [29]. The $\mathrm{H}_{2} \mathrm{O}_{2}$ is transformed into water and oxygen by CAT or GPx. The selenoprotein GPx enzyme removes $\mathrm{H}_{2} \mathrm{O}_{2}$ by using it to oxidize reduced glutathione (GSH) into oxidized glutathione (GSSG). Glutathione reductase, a flavoprotein enzyme, regenerates GSH from GSSG, with NADPH as a source of reducing power (Figure 1).

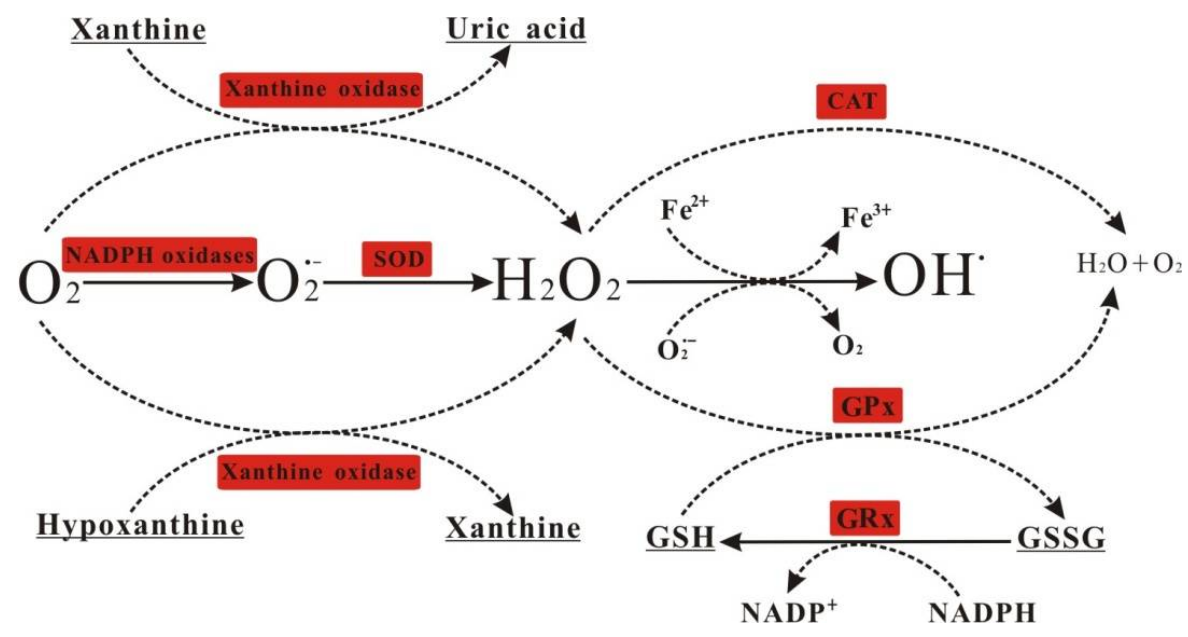

Figure 1: A schematic diagram showing the production of free radicals via different routes and the interaction between intracellular antioxidants. $\mathrm{SOD}=$ superoxide dismutase; CAT= catalase; $\mathrm{GPx}=$ glutathione peroxidase; $\mathrm{GRx}=$ glutathione reductase; GSH=reduced GSH (L-y-glutamyl-L-cysteinyl-glycine); GSSG=0xidized GSH 


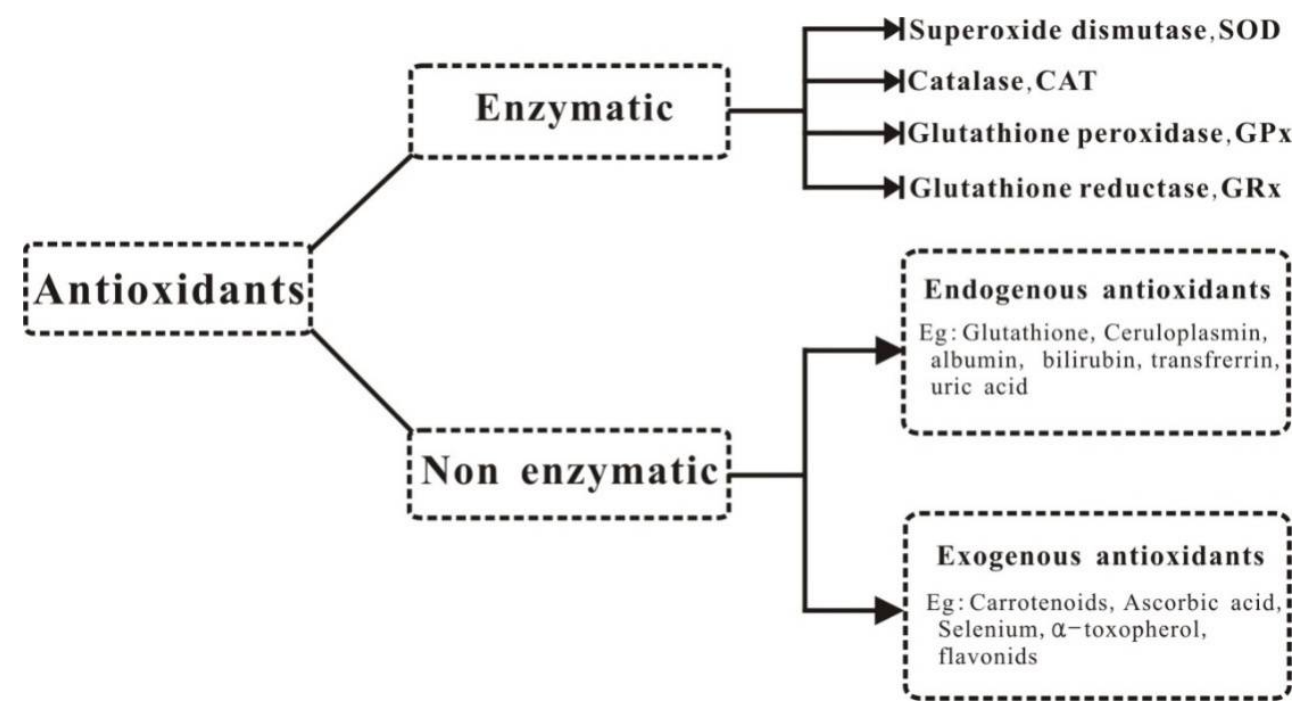

Figure 2: Enzymatic and non-enzymatic classification of antioxidants

The non-enzymatic antioxidants are also divided into endogenous (metabolic) and exogenous (nutrient) antioxidants. Endogenous antioxidants are produced by metabolism in the body, such as lipoid acid, glutathione, L-ariginine, coenzyme Q10, melatonin, uric acid, bilirubin, metalchelating proteins, transferrin [30]. Exogenous antioxidants are compounds that cannot be produced in the body, such as vitamin E, vitamin $C$, carotenoids, trace metals (selenium, manganese, zinc), flavonoids, omega- 3 and omega- 6 fatty acids. These exogenous antioxidants must be provided by foods or supplements via diet.

\section{PLANTS AS SOURCES OF NATURAL ANTIOXIDANTS}

Despite the fact that humans are equipped with an impressive repertoire of antioxidant enzymes as well as small antioxidant molecules, these agents may not be sufficient enough to normalize the redox status during oxidative stress [31]. Antioxidant supplementation/treatment has been adopted for maintaining optimal cellular functions. There are a number of synthetic phenolic antioxidants that have been widely used as food antioxidants, such as butylated hydroxyanisole (BHA), butylated hydroxytoluene (BHT) and ter-butylhydroquinone (TBHQ) [32]. However, some physical properties of synthetic antioxidants, such as their high volatility and instability at elevated temperatures, carcinogenic nature and consumers' preference for natural ingredients have reinforced the efforts for the development of alternative antioxidants from natural origins.

Plants, especially medicinal herbs, have been used for the prevention and/or treatment of several diseases since very old times [33]. Plant extracts, such as flavonoids and phenolics, have raised public interest in their potential to act as antioxidants. Natural antioxidants can strengthen the endogenous antioxidant defense from ROS ravage and restore the optimal balance by neutralizing the reactive species [34]. In traditional Chinese medicine (TCM), a similar concept of balance between anti-oxidation and oxidation called yin-yang has existed for more than 2000 years [35]. 'Yang-invigorating' action usually associates with immune-enhancement and energy generation enhancement, i.e., through the enhancement of the mitochondrial oxidative process, while 'yin-nourishing' action suppress the symptom of heat-fire or 'yang' i.e., preventing the over oxidation process [36]. Maintaining yin and yang in harmony is akin to attaining the homeostatic state. An imbalance between ROS and the inherent antioxidant capacity of the body, has directed the use of dietary and/or medicinal supplements particularly during the disease attack [36]. The epidemiological studies have demonstrated an inverse association between ingestion of these natural antioxidants and mortality from agerelated diseases, such as coronary heart diseases and cancer [37]. Based on a recent large-scale research [38], large number of medicinal plants has been identified as having potential antioxidant activities [39-42]. The raw extracts or isolated pure compounds from medicinal plants are more effective antioxidants in vitro than BTH or vitamin E $[43,44]$. Moreover, the medicinal plants also exhibit far stronger antioxidant activity and contain significantly higher levels of phenolic compounds than common vegetables and fruits [38]. Therefore, the medicinal plants are promising sources of natural antioxidants [45]. 


\section{Structures and classes of polyphenols}

Polyphenols are secondary metabolites of plants and generally involved in defense against ultraviolet radiation or aggression by pathogens [46]. They comprise a wide variety of molecules that have polyphenol structures, i.e. several hydroxyl groups on aromatic rings, but also molecules with one phenol rings, such as phenolic acid and phenolic alcohols. According to the number of phenol rings that they contain and to the structural elements that bind these rings to one another, polyphenols are classified into different groups, including phenolic acids, flavonoids, stilbenes and lignans [47]. Flavonoids and phenolic acids have been considered as the major contributors to the antioxidant activity in medicinal plants [47].

Flavonoids comprise the most abundant group of plant polyphenols [48]. Their common structural feature is the diphenylpropane moiety, which consists of two aromatic rings linked through three carbon atoms that together usually form an oxygenated heterocycle (Figure 3). Based on the variation in the type of heterocycle involved, flavonoids are divided into six classes: flavones, flavanones, flavonols, isoflavones, anthocyanidins and flavanols (or catechins) (Figure 3). Flavonols are the most ubiquitous flavonoids in foods with quercetin and kaempferol as the more representative compounds. Phenolic acids can be divided in two classes: derivatives of benzoic acid and derivatives of cinnamic acid (Figure 3 ). The hydroxybenzoic acids, such as gallic acid and protocatechuic acid, are found in very few edible plants, except for certain red fruits, black radish, and onions [49]. The hydroxycinnamic acids are more common than are the hydroxybenzoic acids and consist chiefly of p-coumaric, caffeic, ferulic, and sinapic acids. Gallic acid, the precursor of many tannins, is one of the most studied and promising compounds in the hydroxybenzoic group, while cinamic acid is the precursor of all the hydroxycinnamic acids [50].

\section{CLINICAL EFFECTS OF POLYPHENOLS IN OXIDATIVE STRESS-RELATED DISEASES}

It is well established that consumption of polyphenol-rich foods may increase plasma antioxidant capacity $[51,52]$. This increase in the anti-oxidative capacity of plasma may be explained either by the presence of reducing polyphenols and their metabolites in plasma, by their effects upon concentrations of other reducing agents (endogenous antioxidants), or by their effect on the absorption of pro-oxidative food components, such as iron [47]. Epidemiological studies have repeatedly shown that polyphenols, as antioxidants may protect cell constituents against oxidative damage and therefore limit the risk of various degenerative diseases associated with oxidative stress [53].

\section{Polyphenols and aging}

Aging can generally be defined as a progressive decline in the efficiency of biochemical and physiological processes after the reproduction phase of life. It is a natural accumulation process of diverse detrimental changes in cells and tissues, leading to the disabilities and diseases that limit normal body functions [54]. Among the theories proposed for the explaining the mechanism of aging [55-57], free radical/oxidative stress theory is one of the most accepted [58]. Although a certain amount of oxidative damage takes places under normal conditions, the rate of this damage significantly increases during the aging process as the efficiency of anti-oxidative and repair mechanisms decrease [59].

Anthocyanins are particularly abundant in brightly colored fruits such as berry fruits and concord grapes and grape seeds. They have been shown to have potent antioxidant/anti-inflammatory activities, as well as to inhibit lipid peroxidation and the activity of cyclo-oxygenase (COX)-1 and -2 [60]. Fruit and vegetable extracts that have high levels of flavonoids also display high total antioxidant activity. It is reported that the dietary supplementation with spinach, strawberry or blueberry extracts in a control diet were effective in reversing aging-related deficits in brain and behavioral function in aged rats [61]. Tea catechins have been shown to possess strong anti-aging activity and consuming green tea rich in these catechins may delay the onset of aging [62]. Resveratrol is a very recent entry as an antiaging agent for preventing oxidative stressinduced aging in endothelia cells by preventing ROS-induced damage via increased expression of endothelia silencing information regulator (SIRT1). SIRT1 belongs to the nicotinamide adenine dinucleotide $\left(\mathrm{NAD}^{+}\right)$dependent histone deacetylase family regulates gene silencing and is believed to mediate the beneficial effects on health and longevity in normal cells by calorie restriction [63].

\section{Polyphenols and cardiovascular disease}

Cardiovascular disease (CVD) is one of the leading causes of death in many developed nations [64]. 
Phenolic acids

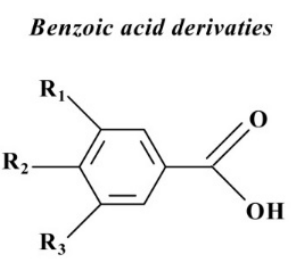

$\mathrm{R}_{1}=\mathrm{R}_{2}=\mathrm{R}_{3}=\mathrm{OH}:$ Gallic acid

$\mathrm{R}_{1}=\mathrm{R}_{2}=\mathrm{OH}, \mathrm{R}_{3}=\mathrm{H}$ : Protocatechuic acid<smiles>[R3]c1cc(-c2oc3cc(O)cc(O)c3c(=O)c2O)cc([R3])c1[R4]</smiles>

$\mathrm{R}_{1}=\mathrm{R}_{2}=\mathrm{OH}, \mathrm{R}_{3}=\mathrm{H}$ : Quercetin<smiles>O=C1CC(c2cc(Br)c(Br)c(Br)c2)Oc2cc(O)cc(O)c21</smiles>

$\mathrm{R}_{1}=\mathrm{R}_{3}=\mathrm{H}, \mathrm{R}_{2}=\mathrm{OH}$ : Naringenin<smiles></smiles>

$\mathrm{R}_{1}=\mathrm{R}_{2}=\mathrm{OH}, \mathrm{R}_{3}=\mathrm{H}$ : Cyanidin
Cinnamic acid derivatives<smiles>[R]c1ccc(C=CC(=O)O)cc1[R]</smiles>

$\mathrm{R}_{1}=\mathrm{OH}$ : Coumaric acid $\mathrm{R}_{1}=\mathrm{R}_{2}=\mathrm{OH}:$ Caffeic acid<smiles>[R3]c1cc(-c2cc(=O)c3c(O)cc(O)cc3o2)cc([R3])c1[R4]</smiles>

$\mathrm{R}_{1}=\mathrm{R}_{3}=\mathrm{H}, \mathrm{R}_{2}=\mathrm{OH}$ : Apigenin

Isoflavones<smiles>[R]c1cc(O)cc2occ(-c3ccc(O)cc3)c(=O)c12</smiles>

$\mathrm{R}_{1}=\mathrm{OH}$ : Genistein<smiles>[R4]c1cc(C2Oc3cc(O)cc(O)c3CC2O)cc([R4])c1[R4]</smiles>

$\mathrm{R}_{1}=\mathrm{R}_{2}=\mathrm{OH}, \mathrm{R}_{3}=\mathrm{H}$ : Catechins

Figure 3: Structural features of main classes of phenolics

CVD is a chronic, multi-factorial disease in which a range of genetic and environmental factors plays a role in its initiation, progression and development $[65,66]$. Arteriosclerosis (hardening of the arteries), one of the classical examples of an ROS-mediated CVD, is the result of oxidative modification of low density lipoprotein (LDL) in the arterial walls [67]. Many human studies have showed an association of moderate intake of alcoholic drinks containing polyphenols with a reduced risk of coronary heart diseases [68-70]. The mechanisms by which polyphenols may be protective against CVD are inhibiting LDL oxidation inhibiting platelet aggregation and reducing inflammatory response $[71,72]$.
Resveratrol is the active compound in red wine which is attributed for "French Paradox", the low incidence of CVD despite the intake of high-fat diet and smoking among the French [73]. Studies have shown that resveratrol potentially inhibits the oxidation of the LDL particles via chelating copper or by direct scavenging of the free radicals [74,75]. Meanwhile, resveratrol can prevent platelet aggregation via preferential inhibition of COX-1 activity, which synthesizes thromboxane A2, an inducer of the platelet aggregation and vasoconstrictor [76]. In addition, quercetin has been shown to be inversely associated with mortality from coronary heart disease by inhibiting the expression of metalloproteinase1 (MMP1), and the disruption of atherosclerotic plaques [72]. 


\section{Polyphenols and cancer}

Carcinogenesis is a multistage process and can be divided into three stages: initiation, promotion and progression. ROS can act in all these stages of carcinogenesis [77]. The anticancer effects of polyphenols have been observed at various sites, such as mouth, stomach, duodenum, colon, liver, lung, mammary gland and skin. Many polyphenols, such as quercetin, catechins, isoflavones, ligans, flavanones, ellagic acid, resveratrol have been tested; all of them showed protective effects in some models although their mechanism of action were found to be different [78].

Several mechanisms of action have been identified for anticancer effects of polyphenols. These include removal of carcinogenic agents [79], modulation of cancer cell signaling [80] cell cycle progression [81], promotion of apoptosis [82] and modulation of enzymatic activities [83]. For example, polyphenols influence the metabolism of pro-carcinogens by modulating the expression of cytochrome P450 enzymes involved in their activation to carcinogens. Furthermore, they may modulate the activity of signaling pathways, such as MAPK kinase and PI3 kinase, which are involved in cancer proliferation [84].

\section{Polyphenols and neurodegeneration}

Neurodegenerative disorders such as Parkinson's and Alzheimer's diseases represent an increasing problem in our aging societies [85]. Mitochondrial dysfunction and oxidative damage have been identified as the risk factors for neurodegenerative diseases [85]. Because polyphenols are highly antioxidative in nature, their consumption may provide protection in neurological diseases. For example, polyphenolrich Ginkgo biloba extracts have been shown to be neuroprotective by protecting hippocampal neurons from nitric oxide- and beta-amyloidinduced neurotoxicity [86]. Anthocyanins and isoflavones can reduce the neurodegeneration associated with accumulation advanced glycation endproducts (AGEs) during normal and abnormal brain aging [87]. In addition, phenolic compounds such as caffeic acid and tyrosol are capable of inducing neuroprotective effects to a similar extent to that seen with flavonoids [88].

\section{CONCLUSION}

There is no doubt that the correct balance between oxidation and reduction is critical in maintaining a healthy biologic system. In this review, we have summarized the chemical features of free radicals as well as their deleterious effects on cell structures. In addition, the potential roles of the natural antioxidants from medicine plants in preventing and repairing damages caused by oxidative stress are presented. For a proper evaluation of their potential health effects, we need more data on the concentrations and metabolic forms that tissues and cells are exposed to after ingestion of plant polyphenols via the diet. In addition, new genomic techniques will give tremendous opportunities to explore this field. The highthrough genomics tools will then be able to increase our understanding on how flavonoids affect metabolic pathways and, as a consequence, affect human health.

\section{ACKNOWLEDGEMENT}

This work was supported by National Natural Science Foundation of PR China (nos. 31100173, 31200382, 31470230, 51320105006, 51274268 and 50904080), China Postdoctoral Science Foundation (No. 2012M521562 and 2013M540643) and Postdoctoral Science Foundation of Central South University (no. 502080023).

\section{CONFLICT OF INTEREST}

No conflict of interest associated with this work.

\section{CONTRIBUTION OF AUTHORS}

We declare that this work was done by the authors named in this article and all liabilities pertaining to claims relating to the content of this article will be borne by the authors.

\section{REFERENCES}

1. Davies KJ. Oxidative stress: the paradox of aerobic life. Biochem Soc Symp 1995; 61: 1-31.

2. Halliwell B, Gutteridge JMC, editors. Free Radicals in Biology and Medicine. 3rded. Oxford: Clarendon Press; 1999; pp 1-139.

3. Halliwell $B$. The wanderings of a free radical. Free Radic Biol Med 2009; 46: 531-542.

4. Valko M, Leibfritz D, Moncola J, Cronin MD, Mazur M, Telser J. Free radicals and antioxidants in normal physiological functions and human disease. Int $\mathrm{J}$ Biochem Cell Biol 2007; 39: 44-84.

5. Sivanandham $V$. Free radicals in health and diseases-a mini review. Pharmacologyonline 2011, 1: 1062-1077.

6. Juránek I, Bezek S. Controversy of free radical hypothesis: reactive oxygen species-cause or 
consequence of tissue injury? Gen Physiol Biophys 2005; 24: 263-278.

7. Sies H. Oxidative Stress: Oxidants and Antioxidants. Exp Physiol 1997; 82: 291-195.

8. Goldfarb AH. Antioxidants: role of supplementation to prevent exercise-induced oxidative stress. Med Sci Sports Exer 1993; 25: 232-236.

9. Maxwell $B$. Reactive oxygen species in living systemsource, biochemistry and roll. Am J Med 1991; 91: 14S $22 S$.

10. Koppenol W, Moreno JPW, Ischiropoulos H, Beckman JS. Peroxiynitrite, a cloaked oxidant formed by nitric oxide and superoxide. Chem Res Toxicol 1992; 5: 834 842.

11. Pauwels EK, Erba PA, Kostkiewicz M. Antioxidants: A tale of two stories. Drug News Perspect 2007; 20: 579585.

12. Scalbert A, Manach $C$, Morand $C$, Remesy $C$, Jimenez $L$. Dietary polyphenols and the prevention of diseases. Crit Rev Food Sci Nutr 2005; 5: 287-306.

13. Machlin LJ, Bendich A. Free radical tissue damage: protective role of antioxidant nutrients. FASEB J 1987; 1: 441-445.

14. Kunwar A, Priyadarsin KI. Free radicals, oxidative stress and importance of antioxidants in human health. $J$ Med Allied Sci 2011; 1: 53-60.

15. Freeman BA, Crapo JD. Biology of disease: Free radicals and tissue injury. Lab Invest 1982; 47: 412-426.

16. Stadtman ER. Protein oxidation and aging. Free Radic Res 2006; 40: 1250-1258.

17. Dizdaroglu $M$, Jaruga $P$, Birincioglu $M$, Rodriguez H. Free radical-induced damage to DNA: mechanisms and measurement. Free Radic Biol Med 2002; 32: 11021115.

18. Valko M, Izakovic M, Mazur M, Rhodes CJ, Telser J. Role of oxygen radicals in DNA damage and cancer incidence. Mol Cell Biochem 2004; 266: 37-56.

19. Gupta RK, Patel AK, Kumar R, Chugh S, Shrivastav C, Mehra S, Sharma AN. Interactions between oxidative stress, lipid profile and antioxidants in breast cancer: a case control study. Asian Pac J Cancer Prev 2012; 13 : 6295-6298.

20. Inoue M, Sato M, Nishikawa M, Park AM, Kira Y, Imada I, Utsumi K. Mitochondrial generation of reactive oxygen species and its role in aerobic life. Curr Med Chem 2003; 10: 2495-2505.

21. Lenaz G. Mitochondria and reactive oxygen species. Which role in physiology and pathology? Adv Exp Med Biol 2012; 942: 93-136.

22. Drose S, Brandt U. Molecular mechanisms of superoxide production by the mitochondrial respiratory chain. Adv Exp Med Biol 2012; 748: 145-169.

23. Gupta RK, Patel AK, Shah N, Choudhary AK, Jha UK, Yadav UC, Gupta PK. Oxidative stress and antioxidants in disease and cancer: a review. Asian Pac J Cancer Pre 2014; 15: 4405-4409.

24. Toyokuni S. Iron and carcinogenesis: from Fenton reaction to target genes. Redox Rep 2002; 7: 189-197.
25. Gutteride JMC, Mitchell J. Redox-imbalance in the critically ill Br Med Bull 1999; 55: 49-75.

26. Droge W. Free radicals in the physiological control of cell function. Physiol Rev 2002; 82: 47-95.

27. Tiwari AK. Imbalance in antioxidant defense and human diseases: Multiple approach of natural antioxidant therapy. Curr Sci 2001; 8: 1179-1187.

28. Matés JM, Pérez-Gómez C, Núnez de Castro I. Antioxidant enzymes and human diseases. Clin Biochem 1999; 32: 595-603.

29. Landis GN, Tower J. Superoxide dismutase evolution and life span regulation. Mech Ageing Dev 2005; 126: 365379

30. Willcox JK, Ash SL, Catignani GL. Antioxidants and prevention of chronic disease. Crit Rev Food Sci Nutr 2004; 44: 275-295.

31. Seifried HE, Anderson DE, Fisher El, Milner JA. A review of the interaction among dietary antioxidants and reactive oxygen species. J Nutr Biochem 2007; 18: $567-$ 579.

32. Papas AM. Diet and antioxidant status. Food ChemToxicol 1999; 37: 999-1007.

33. Ou B, Huang D, Hampsch-Woodili M, Flanagan JA. When the east meets west: the relationship between yin-yang and antioxidation-oxidation. FASEB J 2003; 17: 127-129.

34. Soobratte MA, Neergheen VS, Luxmimon-Ramma $A$. Phenolic as potential antioxidant therapeutic agents: Mechanism and actions. Muta Res 2005; 579: 200-213.

35. Ni M. The Yellow Emperor's Classic of Medicine: A New Translation of the Neijing Suwen with Commentary. Boston: Shambhala; 1995

36. Siu KM, Mak DHF, Chiu PY, Poon MKT, Du Y, Ko KM. Pharmacological basis of 'Yin-nourishing' and 'Yanginvigorating' actions of Cordyceps, a Chinese tonifying herb. Life Sci 2004; 76: 385-395.

37. Gulcin I. Antioxidant activity of food constituents: an overview. Arch Toxicol 2012; 86: 345-391.

38. Cai YZ, Luo Q, Sun M, Corke H. Antioxidant activity and phenolic compounds of 112 traditional Chinese medicinal plants associated with anticancer. Life Sci 2004; 74: 2157-2184.

39. Katalinic V, Milos M, Kulisic T, Jukic M. Screening of 70 medicinal plants extracts for antioxidant capacity and total phenols. Food Chem 2006; 94: 550-557.

40. Wong CC, Li HB, Cheng KW, Chen F. A systematic survey of antioxidant activity of 30 Chinese medicinal plants using the ferric reducing antioxidant power assay. Food Chem 2006; 97: 705-711.

41. Gan $R Y$, Kuang $L, X u X R$, Zhang $Y$, Xia $E Q$, Song $F L, L i$ $H B$. Screening of natural antioxidants from traditional Chinese medicinal plants associated with treatment of rheumatic disease. Molecules 2010; 15: 5988-5997.

42. Matkowski A, Jamiolkowska-Kozlowska W, Nawrot $L$. Chinese medicinal herbs as source of antioxidant compounds-where tradition meets the future. Curr Med Chem 2013; 20: 984-1004. 
43. Gu LW, Weng XC. Antioxidant activity and components of Salvia plebeian R.Br. - a Chinese herb. Food Chem 2001; 73: 299-305.

44. Pyo YH, Lee TC, Logendrac RT. Antioxidant activity and phenolic compounds of Swiss chard (Beta vulgaris subspecies cycla) extracts. Food Chem 2004; 85: 19-26.

45. Krishnaiah $D$, Sarbatly $R$, Nithyanandam. A review of the antioxidant potential of medicinal plant. Food Bioprod Process 2011; 89: 217-233.

46. Beckman CH. Phenolic-storing cells: keys to programmed cell death and periderm formation in wilt disease resistance and in general defence responses in plants? Physiol Mol Plant Pathol 2000; 57: 101-110.

47. Pandey KB, Rizvi SI. Plant polyphenols as dietary antioxidants in human health and disease. Oxi Med Cell Longev 2009; 2: 270-278.

48. Procházková $D$, Boušová I, Wilhelmová N. Antioxidant and prooxidant properties of flavonoids. Fitoterapia 2011; 82: 513-523.

49. Shahidi F, Naczk M, editors. Food phenolics, sources, chemistry, effects, applications. Lancaster: Technomic Publishing Co Inc; 1995.

50. Kähkönen MP, Hopia Al, Heikki JV, Rauha JP, Pihlaja K, Kujala TS, Heinonen M. Antioxidant activity of plant extracts containing phenolic compounds. J Agric Food Chem 1999; 47: 3954-3962.

51. Duthie GG, Pedersen MW, Gardner PT, Morrice PC, Jenkinson AM, McPhail DB, Steele GM. The effect of whisky and wine consumption on total phenol content and antioxidant capacity of plasma from healthy volunteers. Eur J Clin Nutr 1998; 52: 733.

52. Young JF, Nielsen SE, Haraldsdóttir J, Daneshvar B, Lauridsen ST, Knuthsen P, Crozier A. Effect of fruit juice intake on urinary quercetin excretion and biomarkers of antioxidative status. Am J Clin Nutr 1999; 69: 87-94.

53. Arts ICW, Hollman PCH. Polyphenols and disease risk in epidemiologic studies. Am J Clin Nutr 2005; 81: 317325.

54. Armbrecht $\mathrm{Hj}$. The biology of ageing. J Lab Clin Med 2001; 138: 220-225.

55. Finkel T, Holbrook NJ. Oxidants, oxidative stress and the biology of ageing. Nature 2000; 408: 239-247.

56. Balaban RS, Nemoto S, Finkel T. Mitochondria, oxidants, and ageing. Cell 2005; 120: 483-495.

57. Biesalski HK. Free radical theory of ageing. Curr Opin Clin Nutr Metab Care 2002; 5: 5-10.

58. Harman D. Free radical theory of aging: an update: increasing the functional life span. Ann NY Acad Sci 2006: 1067: 1-12.

59. Rizvi SI, Maurya PK. Markers of oxidative stress in erythrocytes during aging in human. Ann NY Acad Sci 2007; 1100: 373-382.

60. Zafra-Stone S, Yasmin T, Bagchi M, Chatterjee A, Vinson J.A, Bagchi D. Berry anthocyanins as novel antioxidants in human health and diseases prevention. $\mathrm{Mol}$ Nutr Food Res 2007; 51: 675-683.
61. Shukitt-Hale B, Lau FC, Joseph JA. Berry fruit supplementation and the aging brain. $J$ Agric Food Chem 2008; 56: 636-641.

62. Maurya PK, Rizvi SI. Protective role of tea catechins on erythrocytes subjected to oxidative stress during human aging. Nat Prod Res 2009; 23: 1072-1079.

63. Kao CL, Chen LK, Chang YL, Yung MC, Hsu CC, Chen $Y C$, et al. Resveratrol protects human endothelium from $H(2) O(2)$-induced oxidative stress and senescence via SirT1 activation. J Atheroscler Thromb 2010; 17: 970979.

64. Vauzour D, Rodriguez-Mateos A, Corona G, OrnaConcha MJ, Spencer JPE. Polyphenols and human health: prevention of disease and mechanisms of action. Nutrients 2010; 2: 1106-1131.

65. Tanasescu M, Leitzmann MF, Rimm EB, Willett WC, Stampfer MJ, Hu FB. Exercise type and intensity in relation to coronary heart disease in men. JAMA 2002; 288: 1994-2000.

66. Ambrose JA, Barua RS. The pathophysiology of cigarette smoking and cardiovascular disease: An update. J Am Coll Cardiol 2004; 43: 1731-1737.

67. Vogiatzi G, Tousoulis D, Stefanadis C. The role of oxidative stress in atherosclerosis. Hell J Cardiol 2009; 50: 402-409.

68. Agewall S, Wright S, Doughty RN, Whalley GA, Duxbury $M$, Sharpe $N$. Does a glass of red wine improve endothelial function? Eur Heart J 2000; 21: 74-78.

69. Hashimoto M, Kim S, Eto M, lijima K, Ako J, Yoshizumi M, AkishitaM, Kondo K, Itakura $\mathrm{H}$, Hosoda $\mathrm{K}$ et al. Effect of acute intake of red wine on flow mediated vasodilatation of the brachial artery. Am J Cardiol 2001; 88: 1457-1460.

70. Whelan AP, Sutherland WH, McCormick MP, Yeoman $D J$, de Jong SA, Williams MJ. Effects of white and red wine on endothelial function in subjects with coronary artery disease. Intern Med J 2004; 34: 224-228.

71. Nardini M, Natella $F$, Scaccini C. Role of dietary polyphenols in platelet aggregation. A review of the supplementation studies. Platelets 2007; 18: 224-243.

72. García-Lafuente A, Guillamón E, Villares A, Rostagno MA, Martínez JA. Flavonoids as anti-inflammatory agents: implications in cancer and cardiovascular disease. Inflamm Res 2009; 58: 537-552.

73. Shakibaei M, Harikumar KB, Aggarwal BB. Resveratrol addiction: to die or not to die. Mol Nutr Food Res 2009; 53: 115-128.

74. Wallerath $T$, Deckert G, Ternes $T$, Anderson $\mathrm{H}, \mathrm{Li} H$, Witte K, Forstermann U. Resveratrol, a polyphenolic phytoalexin present in red wine, enhances expression and activity of endothelial nitric oxide synthase. Circulation 2002; 106: 1652-1658.

75. Gresele P, Pignatelli P, Guglielmini G, Carnevale R, Mezzasoma AM, Ghiselli A, Momi S, Violi F. Resverarol, at concentrations attainable with moderate wine consumption, stimulates human platelet nitric oxide production. J Nutr 2008; 138: 1602-1608 
76. Pirola L, Frojdo S. Resveratrol: one molecule, many targets. IUBMB Life 2008; 60: 323-332.

77. Valko M, Rhodes CJ, Moncol J, Izakovic M, Mazur M. Free radicals, metals and antioxidants in oxidative stress-induced cancer. Chem Biol Interact 2006; 160: 1 40.

78. Johnson I.T, Williamson G, Musk SR. Anticarcinogenic factors in plant foods: $A$ new class of nutrients. Nutr Res Rev 1994; 7: 175-204.

79. Owen RW, Giacosa A, Hull WE, Haubner $R$, Spiegelhalder $B$, Bartsch $H$. The antioxidant/anticancer potential of phenolic compounds isolated from olive oil. Eur J Cancer 2000; 36: 1235-1247.

80. Corona G, Deiana M, Incani A, Vauzour D, Dessi MA, Spencer JP. Inhibition of p38/CREB phosphorylation and $C O X-2$ expression by olive oil polyphenols underlies their anti-proliferative effects. Biochem Biophys Res Commun 2007; 362: 606-611.

81. Corona $G$, Deiana $M$, Incani A, Vauzour D, Dessi MA, Spencer JP. Hydroxytyrosol inhibits the proliferation of human colon adenocarcinoma cells through inhibition of ERK1/2 and cyclin D1. Mol Nutr Food Res 2009; 53 : 897-903.

82. Mantena SK, Baliga MS, Katiyar SK. Grape seed proanthocyanidins induce apoptosis and inhibit metastasis of highly metastatic breast carcinoma cells. Carcinogenesis 2006; 27: 1682-1691.

83. Adams LS, Chen S. Phytochemicals for breast cancer prevention by targeting aromatase. Front Biosci 2009; 14: 3846-3863.

84. Wang W, Wang $X$, Peng $L$, Deng $Q$, Liang $Y$, Qing $H$, Jiang $B$. CD24-dependent MAPK pathway activation is required for colorectal cancer cell proliferation. Cancer Sci 2010; 101: 112-119.

85. Nussbaum RL, Ellis CE. Alzheimer's disease and Parkinson's disease. N Engl J Med 2003; 348: 13561364.

86. Tchantchou F, Xu Y, Wu Y, Christen Y, Luo Y. EGb 761 enhances adult hippocampal neurogenesis and phosphorylation of CREB in transgenic mouse model of Alzheimer's disease. FASEB J 2007; 21: 2400-2408.

87. Hsieh HM, Wua WM, Hu ML. Soy isoflavones attenuate oxidative stress and improve parameters related to aging and Alzheimer's disease in C57BL/6J mice treated with D-galactose. Food Chem Toxicol 2009; 47: 625-632.

88. Vauzour D, Cornona G, Spencer JP. Caffeic acid, tyrosol and p-coumaric acid are potent inhibitors of 5-Scysteinyl-dopamine induced neurotoxicity. Arch Biochem Biophy 2010; 501: 106-111. 